\title{
Animal Enclosure
}

National Cancer Institute

\section{Source}

National Cancer Institute. Animal Enclosure. NCI Thesaurus. Code C94850.

An area intended to confine animals. 